\title{
Kebijakan Mengenai Lobster
}

The Impact of Minister of Marine Affairs and Fisheries Regulation Number 12 of 2020 on the Sustainability of Lobster in Indonesia

Telah diketahui bahwa Indonesia disebut sebagai Negara Maritim, dimana itu artinya Indonesia dikelilingi oleh berbagai macam kepulauan. Hal tersebut secara tidak langsung, Indonesia juga memiliki beragam jenis hewan laut yang dapat dimanfaatkan sebagai hiasan maupun santapan bagi masyarakat Indonesia. Tentunya keuntungan yang dimiliki Indonesia dengan kondisi yang seperti itu, tidak sedikit pula sebagian masyarakat Indonesia berprofesi menjadi nelayan untuk memperoleh pendapatan dari hasil pencaharian mereka di perairan. Namun, sangat disayangkan beberapa nelayan saat melakukan profesi mereka tidak memperhatikan efek kedepannya, yang dimana sebagian nelayan ada yang menggunakan alat penangkapan mereka tidak sesuai kebijakan yang telah dibuat. Ditakutkannya pula ini akan berdampak pada populasi hidup hewan tersebut, terutama untuk hewan lobster dan kepiting. Dikarenakan, kedua hewan tersebut menjadi incaran para nelayan sebab harganya yang jika dijual lumayan mahal dan rasanya sendiri bila dikonsumsi sungguh nikmat sehingga permintaan masyarakat akan kedua hewan tersebut terus menerus tiada henti. Jadi, pemerintah membuat kebijakan yang telah diatur dalam Peraturan Menteri Kelautan dan Perikanan Nomor 12 Tahun 2020 tentang Pengelolaan kepiting dan lobster di wilayah NKRI.

Namun, setelah pembuatan kebijakan itu dibuat menuai pro dan kontra sebab dalam kebijakan itu menekankan melakukan ekspor benih lobster yang nantinya dikhawatirkan akan mengancam keberlangsungan lobster itu sendiri. Tetapi saat adanya pro dan kontra itu terjadi, peraturan ini menenkankan kembali bahwa para eksportir yang melakukan kegiatan ekspor wajib melakukan pembudidayaan lobster didalam negeri dengan melibatkan pembudidaya lokal. Dan telah dibatasi kuota penangkapan benih lobster yang telah ditetapkan dengan alokasi sebesar 70\% untuk pembudidayaan dan 30\% untuk kegiatan ekspor. Dalam kebijakan yang telah diperbarui ini, akan diberlakukan legalisasi benih lobster ekspor yang telah dikaji juga oleh beberapa tim ahli. Hal ini akan menguntungkan banyak pihak pula, seperti nelayan dan pembudidaya lokal memperoleh nilai ekonomis, eksportir memperoleh keuntungan, negara mendapatkan pemasukan juga, penyelundupan lobster menjadi berkurang, dan diharapkan ribuan nelayan akan bergantung pada hasil benih lobster yang telah 
dibudidayakan oleh para eksportir dengan pembudidaya lokal. Dan di tahun 2024, Indonesia ingin menerapkan beberapa strategi dalam membudidayakan lobster, salah satunya mengembangkan sistem rantai pasokan hulu-hilir.

Rizki Akbar, 130118061 